\title{
Os súditos de Momo na República branca: cronistas e carnaval na imprensa carioca
}

\author{
The subjects of Momo in the white Republic: \\ chronicles and carnival in the press in Rio de Janeiro
}

\author{
Vera Lúcia Bogéa Borges \\ Departamento de História da Universidade Gama Filho. \\ veraborges@globo.com
}

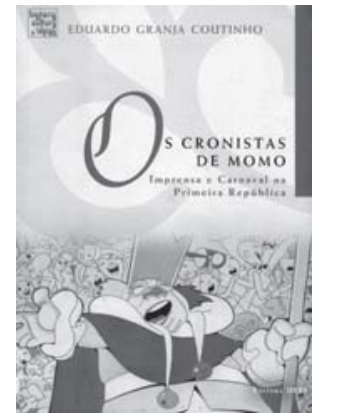

Coutinho, Eduardo Granja.

Os cronistas de Momo: imprensa e carnaval na Primeira República. Rio de Janeiro: Ed. UFRJ, 2006. 203 p. (Col. História, Cultura e Idéias, 5).
S oberano da folia carnavalesca, Momo é a personificação do sarcasmo e, ao longo do tempo, tornou-se elemento central de uma farsa na qual costumes sociais são questionados por um humor em que irreverência e crítica são ingredientes imprescindíveis. O carnaval como objeto de pesquisa já mereceu inúmeros trabalhos acadêmicos. Nesse belo livro, a inovação trazida por Eduardo Coutinho está no debate em torno do cronismo carnavalesco, isto é, a estrutura do noticiário especializado dessa festa que tem como cenário a cidade do Rio de Janeiro.

Nas últimas décadas do século XIX, a modernização dos processos de impressão, além de baratear o preço dos jornais, permitiu a diversificação gráfica e o aumento do número de publicações. Dessa forma, não só a imprensa modernizada chacoalhava os costumes cariocas, mas também a festa carnavalesca transformava-se, ao permitir a presença da cultura popular no espaço público burguês por intermédio dos textos das colunas de Momo que, diariamente, invadiam os lares mais abastados da capital. Como naquele período a idéia-síntese da cidade resumia-se a 'o Rio civiliza-se', a transformação se processava purgando a violência e a desordem típicas do entrudo, que dava lugar ao moderno carnaval, obediente a padrões estabelecidos. Portanto a imprensa de Momo não só modelava a festa carnavalesca e permitia sua incorporação à cultura oficial, como a tornava expressão da nacionalidade brasileira. Assim, Coutinho compreende os cronistas carnavalescos como mediadores, integrantes de uma 'intelectualidade marginal' que militava em prol da cultura negra ainda reprimida pelas arbitrariedades policiais impostas pelos padrões civilizatórios europeus. $\mathrm{O}$ autor assume uma posição que relativiza a compreensão de Althusser acerca da imprensa, ao pensá-la - ainda que de forma secundária - também como expressão dos interesses e anseios dos grupos subalternos.

Mas, afinal, quem eram esses cronistas? É importante ter em mente que esses 'súditos de Momo' eram jornalistas, boêmios e, antes de mais nada, ardorosos foliões. Vagalume, Jota Efegê, Peru dos Pés Frios foram alguns dos nomes que transformaram a paixão pessoal em assunto profissional e inauguraram a reportagem carnavalesca. Oriundos das camadas mais baixas da sociedade, ligados às religiões afro-brasileiras e freqüentadores de terreiros das tias baianas da Cidade Nova, 
esses cronistas viviam a ambigüidade de serem, a um só tempo, agentes de uma empresa jornalística e promotores do carnaval.

Eduardo Coutinho, além de investigar a origem social desses profissionais, discute suas aspirações, seus valores, suas práticas e o lugar que ocupavam nas redações dos jornais, que reservavam, na época, seleto espaço aos editorialistas, repórteres políticos e redatores dos artigos de fundo. A contradição marcava a vida desse 'baixo clero' do jornal, isto é, dos repórteres sem títulos, status ou diplomas que se dedicavam a assuntos populares naquela 'República de doutores'. Apesar de conhecidos no exercício de seu ofício pelos apelidos - o que demarcava o seu relato pelo prisma do personagem da festa carnavalesca -, jamais podiam assumir abertamente suas preferências pessoais, como ocorreu com Francisco Guimarães, dito Vagalume, que se dizia católico apostólico romano apesar de seguidor das leis dos orixás. Como afirma o autor, "entre padres e babalorixás, o cronista demonstrava maior reverência por estes últimos" (p.107).

Ademais, os cronistas eram em número expressivo. Formavam uma multidão de foliões, a ponto de o autor apresentar uma lista exaustiva de pseudônimos, acompanhados dos respectivos nomes e jornais em que trabalhavam. A primazia do folião sobre o jornalista é inegável. Um episódio bastante revelador envolve José Luís Cordeiro, vulgo Jamanta, empregado no Correio da Manhã, tido como um jornal anticarnavalesco. O jornalista foi advertido pelo severo secretário Heitor Melo, pois um funcionário daquele jornal não podia ser integrante do Clube dos Democráticos nem, muito menos, desfilar em carros de críticas ou de alegorias pelas ruas. Para garantir a eficácia da repreensão, no dia do desfile a redação o enviou para bem longe do centro da cidade, para o longínquo bairro de Santa Cruz. Diga-se de passagem que os colegas de trabalho de Jamanta deram grande atenção à exibição dos Democráticos. Por falta de sorte do cronista, que contrariava a ordem recebida, um problema no carro alegórico que trazia uma garrafa gigante estragou seus planos. Escondido no interior da garrafa, e não suportando mais a demora e o calor, eis que salta dela o jornalista folião. Aplaudido por quase todos e diante do espanto do zeloso secretário do Correio da Manhã, Jamanta não perdeu a pose, atirou-lhe um beijo e ainda teve fôlego para gritar "Viva o Correio da Manhã! Viva o Clube dos Democráticos!" (p.132).

O nascimento da crônica da folia recebe um capítulo específico na análise de Eduardo Coutinho. No início os cronistas fixavam-se no carnaval da elite, mas pouco a pouco a festa, que ganhou a condição de paixão nacional, virou assunto e, portanto, negócio importante para a empresa jornalística. A imprensa passou a prestar atenção às atividades das grandes sociedades carnavalescas que surgiam em clubes como Tenentes do Diabo (1855), Democráticos (1867) e Os Fenianos (1869). Cada agremiação tinha, além da sua publicação oficial, alguns outros títulos que circulavam pelos bailes pré-carnavalescos. Nos dias de carnaval, esses jornais eram distribuídos pelas ruas com o intuito de esclarecer a população sobre o sentido das críticas e o significado das alegorias. Essas edições adotavam um estilo debochado, e apresentavam como inovação literária os chamados pufes, termo emprestado 
do inglês puff, assoprar, que tinha como finalidade instigar os foliões, "convocando-os à orgia, à loucura e ao prazer. Em prosa ou em verso, os pufes eram textos hiperbólicos com os quais as grandes sociedades descreviam de maneira pomposa seus próprios bailes e préstitos, alfinetavam os clubes rivais, faziam críticas sociais e adoravam o deus da pilhéria" (p.37).

Aos poucos os pufes passaram a ser estampados nas edições dos jornais comerciais. Inicialmente gratuitos, conforme conquistaram os corações dos leitores tornaram-se matéria paga. Segundo o autor, o primeiro grande jornal adepto da novidade foi Gazeta de Notícias, a mais carnavalesca das folhas da imprensa nacional. "Desde a década de 1870, os jornais da corte perceberam o filão mercadológico da festa popular, destinando um espaço cada vez maior à cobertura dos festejos de Momo" (p.39). Desse modo, a crônica - compreendida como o conjunto das matérias que compõem o noticiário do carnaval com base em textos informativos e literários - tinha um papel importante na transformação da vida cultural brasileira. A cobertura jornalística não se restringia aos dias de folia. O Jornal do Brasil, para citar apenas um periódico, tinha a coluna Pródromos da Folia, que antecipava e prenunciava a festa e era editada até quase a metade do ano, divulgando as repercussões do carnaval e de seu personagem central, Momo, que ainda apresentava fôlego para a brincadeira.

O discurso da crônica carnavalesca começa a mudar com a chegada do século XX. As matérias já não se concentravam na repressão aos festejos populares, mas sim na assimilação do divertimento popular. Incorporado à ordem, o aspecto arrebatador da alma carnavalesca espalhava-se pela cidade. Apesar de alcançarem o direito de brincar livremente o carnaval sem serem importunados pela polícia, os foliões proletários deviam, desde então, estar atentos às regras que lhes eram impostas. Porém as modificações não paravam aí. O comércio especializado nos produtos da festa conquistava cada vez mais espaço nos anúncios de jornais, oferecendo, entre outros itens, instrumentos musicais, fantasias, confete, serpentina e, é claro, lança-perfume. O lucro parecia interminável! Mesmo a alta esfera política não ficava alheia a toda essa movimentação, como expõe Coutinho ao relatar a ida do rancho Ameno Resedá ao Palácio do Catete, em 1911, para apresentarse à família do presidente da República Hermes da Fonseca.

Os eletrizantes anos 20 colocaram em xeque a Primeira República, com destaque para o tenentismo. Os cronistas mostravam de forma positiva o morro, apresentando o cotidiano das favelas cariocas pela ótica de seus moradores e recebendo o reconhecimento da comunidade de sambistas e demais habitantes do universo do samba. Essa marca também foi expressa na música, e já em 1917 a canção "Pelo telefone" acrescentava um aspecto específico ao samba moderno: a letra como crônica da cidade e do país. Os autores não limitavam seus escritos ao denuncismo superficial da imprensa republicana e buscavam, dentro do possível, melhorar as condições de vida do homem comum. Como atentamente observa Coutinho: "alguns representantes do tenentismo momesco pareciam, realmente, estar em sintonia com o baixo oficialato do Exército, defendendo a reforma do Estado e da sociedade, contra o 
poder das oligarquias e as chocantes desigualdades sociais. Nesses cronistas, era recorrente o tema da inexistência no país de instituições democráticas" (p.151).

Esses distintos sujeitos sociais interpretavam à sua maneira os festejos de Momo, que se caracterizavam pela espontaneidade e inspiração satírica. Por corporificarem a vida festiva das ruas e os espaços privilegiados na imprensa carnavalesca, os cronistas não escaparam da repressão, ainda que velada, à cultura popular. E o riso do folião não escapou ao governo. Com o final da Primeira República o Estado nacional encampou o carnaval: a festa oficializada garantia o controle das manifestações de massa. Embora isso não tenha decretado a morte do carnaval, inaugurou-se para ele uma nova fase, a do espetáculo como objeto de consumo. A festa popular tornou-se efetivamente cultura de massa.

A nova etapa da comemoração carioca repercute também na crônica especializada, que perde cada vez mais a sua coloração irreverente e assume contornos vagos, até apresentar-se, já na década de 1970, como um pálido noticiário objetivo e distanciado, em nada parecido com o áureo tempo do folião de profissão repórter.

A edição bem cuidada de Os cronistas de Momo, ilustrada com retratos de cronistas e reprodução de colunas, permite ao leitor mergulhar nos meandros de parte da imprensa daquela época. É um agradável passeio pela Primeira República, que, apesar de sua prática política excludente, curvou-se aos encantos de um reinado que lentamente conquistara a capital.

Ainda no século XIX a representação de Momo foi revelada pelos traços do caricaturista Henrique Fleiuss, no periódico Semana Ilustrada. A consagração de sua dinastia, com toda a pompa, tem origem em $A$ Noite, jornal vespertino que apresentou como estratégia publicitária, na década de 1930, inúmeras reportagens sensacionais que lhe renderam autopromoção, ao mesmo tempo que formaram uma legião de súditos, ainda hoje esbaldando-se no carnaval. O alegre e irônico Momo, filho da Noite e irmão das Hespérides, depois de zombar dos deuses e de suas obras foi expulso do Olimpo, mas ressurgia como elemento constante da História. Foi acolhido pelo Rio de Janeiro, transformandose em rei e figura-símbolo do carnaval da cidade.

Como bem destaca, no Prefácio, o historiador Orlando de Barros, estamos diante de um livro rigoroso, informativo e muito divertido, que tem todos os elementos para ser exaltado, anunciado e alardeado, bem ao estilo dos pufes, tão presentes e irreverentes na imprensa do século XIX. 